\title{
What does migration mean for relations with children and spouses left-behind? Reflections from young married men and women on the move in Vietnam ${ }^{1}$
}

\author{
Catherine Locke ${ }^{2}$, Nguyen Thi Ngan $\mathrm{Hoa}^{3}$ and Nguyen Thi Thanh Tam ${ }^{4}$
}

\begin{abstract}
Whilst newly-wed wives and young mothers have traditionally been 'tied to the bamboo grove' in Vietnam, today nearly as many young married women are migrating from rural to urban areas as young married men. This shift implies a radical break with conventional expectations of young married women as new daughters-in-law and as the mothers of young children. It is also closely related with changes in the expectations young married men have of their wives and of their own parenting roles.
\end{abstract}

This paper uses qualitative life histories from 76 married male and female rural-to-urban migrants in their peak child-bearing years to explore their reflections on the impact of migration on their left-behind children and spouses. The migrants subscribe to social norms of family co-residence and justify their absence in terms of fulfilling their parental or marital roles and actively manage their parenting and marital roles in ways that are strongly gendered.

\section{Introduction}

This paper makes a modest contribution to understanding what migration means for children and spouses who are 'left-behind' by focusing on parenting and marital relations from the perspective of young married men and women migrants. Following Toyota et al (2007), we argue that a significant part of understanding what it is to be 'left-behind' requires exploration of the left-behind's relations with those who leave. This emphasis contrasts with the attention to date that has been concerned primarily with the economic welfare, health and well-being of the left-behind (ibid). We focus on how those who are currently 'leaving behind' children and spouses perceive their migration to influence those they have left-behind. Our paper is therefore partial in that the voices of those currently left-behind are not present, but it is also unusual in that it focuses on the much neglected issue of how young married men and women migrants experience and manage their child-rearing, parenting and conjugal relations in the face of parental and spousal absence.

Whilst newly wed wives and young mothers have traditionally been 'tied to the bamboo grove' in Vietnam (Kabeer and Thi Van Anh 2002), today nearly as many young married women are migrating from rural to urban areas as young married men (GSO 2005). This shift implies a radical break with conventional expectations of young married women as new daughters-in-law and as the mothers of young children. Traditional expectations imply that the new wife's first duty is towards her mother-in-law and child-bearing, particularly the bearing of sons, and early child-rearing (Pham Van Bich 1999, Rydstrom 2006). This shift is also closely related with changes in the expectations young married men have of their wives and of their own parenting roles. The Vietnamese version of the 'love marriage' exhibits some continuity with more traditional marital relations but there has been a clear shift towards

\footnotetext{
${ }^{1}$ This research (RES-167-25-0327) is funded by a grant from the Economic and Social Research Council (ESRC) of the UK and the Department for International Development (DFID). We would like to thank them for their support but stress that all errors and views expressed herein remain the authors. We also would like to thank all the individuals who gave up their valuable time to talk with us about the situation of migrants, ranging from researchers to local officers to migrants. Please send any comments or feedback to c.locke@uea.ac.uk.

${ }^{2}$ School of International Development Studies, UEA, Norwich, UK.

${ }^{3}$ Centre for Gender and Family Studies, Southern Institute for Sustainable Development, Ho Chi Minh.

${ }^{4}$ Institute for Family and Gender Studies, Vietnamese Academy of Social Sciences, Hanoi.
} 
greater conjugal intimacy and nuclearisation of family roles (Goodkind 1996, Summerfield 1997, Hirschman and Minh 2002). These changes occur against a backdrop of rapid economic liberalisation, increasing inequality, including rural-urban differences and gender differences. Whilst the state is withdrawing from social sector investment, it continues to champion high expectations for the role of the family in society (Phinney 2008, Rydstrom 2006). How then do young married women and men maintain their parenting and marital relations with the leftbehind for young families in Vietnam?

\section{Methodology}

This paper uses detailed life history data collected in 2008 from married male and female migrants in their peak child-bearing years to explore their reflections on the impact of their migration on their left-behind children and spouses. It focuses on 76 rural-to-urban migrants to Hanoi and Ho Chi Minh who have at least one child under 8 years of age. The sample includes men and women migrating with their spouses, leaving spouses behind, with spouses migrating elsewhere as well as single, divorced or widowed mothers and fathers (see table 1 below $^{5}$ ) and was drawn in each case from a single ward with a very high incidence of migrants. Of these categories only that of men with spouses 'left-behind' corresponds to the conventional expectations that support married men's migration (Pham Van Bich 1999, Kabeer and Thi Van Anh 2007, Hoang 2008), whilst all the other categories break with these norms to varying degrees.

Table 1: Purposive Sample of Low Income Rural-Urban Migrants in Hanoi and Ho Chi Minh

\begin{tabular}{|l|l|l|l|l|l|}
\hline $\begin{array}{l}\text { At least one child less than } 8 \\
\text { years }\end{array}$ & $\begin{array}{l}\text { Hanoi } \\
\text { Men }\end{array}$ & $\begin{array}{l}\text { Hanoi } \\
\text { Women }\end{array}$ & $\begin{array}{l}\text { HCM } \\
\text { Men }\end{array}$ & $\begin{array}{l}\text { HCM } \\
\text { Women }\end{array}$ & Totals \\
\hline Co-resident with spouse & 5 & 5 & 5 & 5 & 20 \\
\hline Spouse 'left behind' & 5 & 5 & 5 & 5 & 20 \\
\hline Spouse migrating separately & 5 & 5 & 5 & 5 & 20 \\
\hline Separated from spouse/single & 2 & 5 & 4 & 5 & 16 \\
\hline Totals & 17 & 20 & 19 & 20 & 80 \\
\hline
\end{tabular}

Migrants were identified using a combination of gatekeepers, usually local women's officers, but also migrant guest house owners, as well as snowballing to identify migrants in these categories. The life histories involved a two part interview, often conducted consecutively at the preference of the migrants, consisting of a semi-structured questionnaire and a more narrative informal interview that was tape recorded, transcribed and translated ${ }^{6}$. The life histories need to be regarded as a narrative data that expresses the migrant's subjectivities, which are inevitably influenced by their efforts at self-presentation, rather than as factual

\footnotetext{
${ }^{5}$ It was our intention to interview 5 people in each purposive category. However, men with disrupted marital histories proved difficult to identify and reluctant to participate. Men quickly remarry after divorce and few are reluctant to admit or discuss this inevitably painful history. Using a male interviewer in a few cases helped increase male response rates in Ho Chi Minh but was less successful in Hanoi and in both cases we failed to attain our target of five respondents. In contrast, the disrupted marital history of women, for whom divorce is more shameful, is more visible because they rarely remarry and often have children. Although their experiences were extremely painful women were more willing to recall their histories. Less surprisingly, in both cases, willing respondents tended to portray themselves as the 'victims' and their spouse as the party to blame, indicating a further source of selection bias within this purposive category.

${ }^{6}$ Hoa and Tam conducted the overwhelming majority of these interviews and verified every translation. In addition the quality of translation was verified for two interviews by an independent Vietnamese researcher and researchers referred back to Vietnamese transcripts during data interpretation. Ethical clearance was given by the University of East Anglia (UEA) and by the Vietnamese Academy of Social Sciences (VASS) and all names used here are pseudonyms.
} 
accounts. ${ }^{7}$ The data is primarily qualitative giving rich insights into how migrants experience their relations with the left-behind but is supported by structured information about informant's, spouse's and children's moves, residence and schooling. The following analysis is based on a preliminary interpretation of the full dataset but foregrounds the experience of just 16 migrants (the first completed case from each purposive category) which have been subject to more in-depth analysis (see table 2 below).

Table 2: Spouse and Occupation of Sample for In-Depth Analysis

\begin{tabular}{|c|c|c|c|c|}
\hline Name & Sex & Occupation & Spouse & Spouse's job \\
\hline \multicolumn{5}{|c|}{ Hanoi Migrants } \\
\hline Linh & $\mathrm{F}$ & Porter & Migrating together & Porter \\
\hline Mai & $\mathrm{F}$ & Porter & Migrating separately & Construction worker \\
\hline Binh & $\mathrm{F}$ & CD Seller & Left-behind seasonally & Porter/fisherman \\
\hline Tran & $\mathrm{F}$ & Porter & 'Separated' & $\mathrm{n} / \mathrm{a}$ \\
\hline Phong & $\mathrm{M}$ & Barber & Migrating together & Fruit seller \\
\hline Dung & $\mathrm{M}$ & Porter & Migrating overseas & Factory worker \\
\hline Tao & M & Coal Seller & Left-behind & Left-behind, farm work \\
\hline Toan & $\mathrm{M}$ & Coal Seller & Twice Remarried & Left-behind, farm work \\
\hline \multicolumn{5}{|c|}{ Ho Chi Minh Migrants } \\
\hline Hue & $\mathrm{F}$ & Babysitting and errands & Migrating together & Syrup drink seller \\
\hline Huong & $\mathrm{F}$ & Outwork for tailor's shop & Migrating separately & Shrimp farming \\
\hline Kieu & $\mathrm{F}$ & Junk trader & Left-behind & Left-behind, electrician. \\
\hline Chien & $\mathrm{F}$ & Working as seamstress & Widowed & $\mathrm{n} / \mathrm{a}$ \\
\hline Manh & $\mathrm{M}$ & Bicycle repair man & 'Migrating' together & Garment factory worker \\
\hline Hung & $\mathrm{M}$ & Bricklayer & Migrating elsewhere & $\begin{array}{l}\text { Domestic worker in Binh Duong } \\
\text { Province }\end{array}$ \\
\hline Thuat & $\mathrm{M}$ & $\begin{array}{l}\text { Breaks up concrete and street } \\
\text { masseur }\end{array}$ & Left-behind & Left-behind, farm work \\
\hline Duong & $\mathrm{M}$ & Mason & Remarried & Currently pregnant and not working \\
\hline
\end{tabular}

Ho Chi Minh and Hanoi represent contrasting case studies in which institutional barriers and normative gender expectations are respectively lesser and greater for migrants attempting to manage their reproductive lives. In Hanoi, in the north, most migrants come from the nearby Red River Delta (Guest 1998, GSO 2005), where socio-economic indicators are relatively good and where there is a complex legacy of Confucianism and Communism: here circular migration is about investing in the rural homestead that has been left-behind. In Ho Chi Minh, migrants come from all over the country (ibid) with distances and conditions in their home provinces having important implications for their aspirations for the future (see table 3).

Those coming to Ho Chi Minh from the Red River Delta are mostly orientated to sustaining rural families but have to contend with the difficulties of doing so over much greater distances (like Kieu and Thuat). In contrast, many from poorer rural situations in southern, central and northern Vietnam aspire to settle their family in Ho Chi Minh (all except for Manh). Significantly, the rural-urban 'gap' in social and economic circumstances is much lower between the Red River Delta and Hanoi/ Ho Chi Minh than between other rural regions and these cities (see Locke, Nguyen and Nguyen 2008 for further details).

\footnotetext{
${ }^{7}$ Quotations from migrants below, presented in italics, are verbatim translations from the in-depth interviews. Editorial additions to clarify sense are in square brackets.
} 
Table 3: Origins and Aspirations of Ho Chi Minh Sub-Sample Subject to In-Depth Analysis

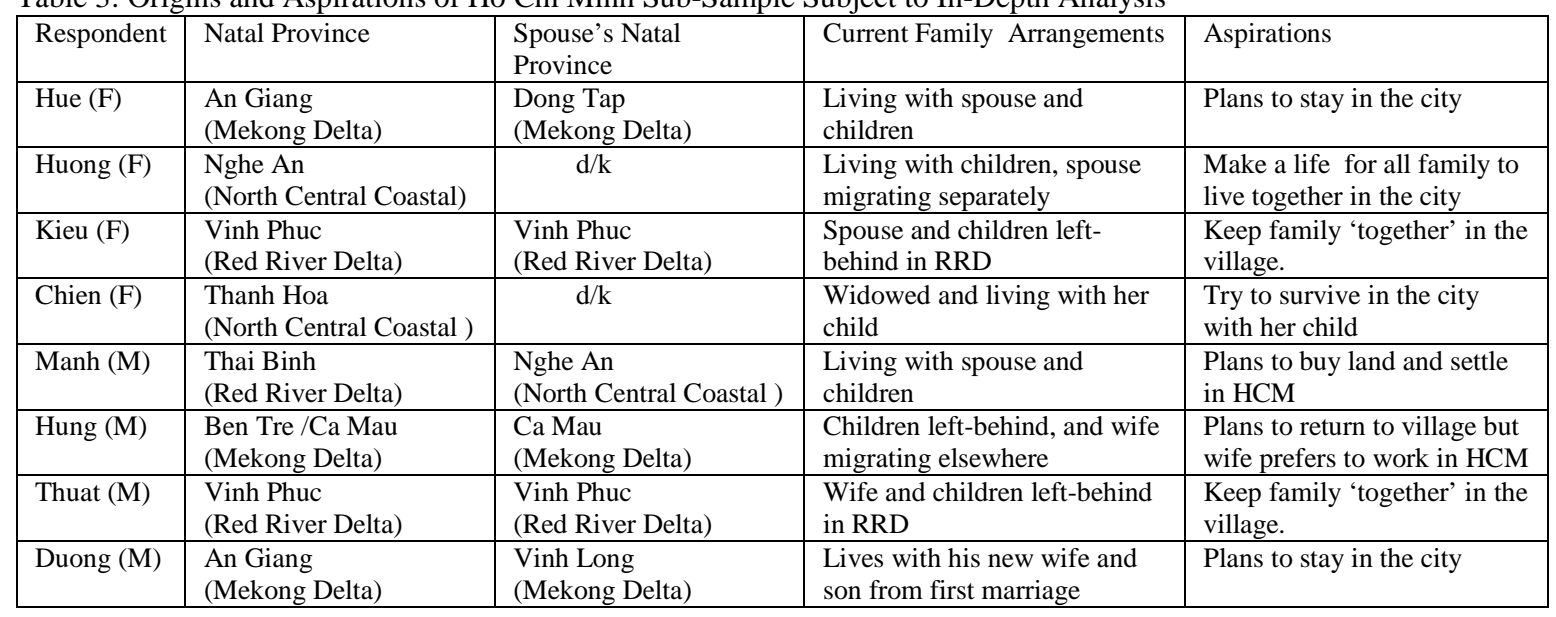

Whilst some migrants are struggling to bring children and spouses too, others are not able to do so and, especially where distances are long, face prolonged separations (see tables 4). The overwhelming majority of low-income migrants to Hanoi leave their young children behind, even where they live together as a couple in the city. Consequently, none of the sub-sample of Hanoi migrants had families who were 'united' with both parents and young children living together. However, most migrants to Hanoi came from the nearby Red River Delta and were able to maintain close links with their rural homes: fathers/husband typically visiting once a month and mothers/wives visiting every couple of weeks. This contrasts with migrants from the Red River Delta working in Ho Chi Minh who were only able to visit annually at Tet, and who occasionally would miss going home at Tet because they had only recently arrived, had not got enough money to take home gifts or needed to save money. Whilst migrants to Ho Chi Minh from the Mekong Delta were able to visit home more easily they maintained rather looser contacts than the short distant migrants to Hanoi: with women often visiting every month and men every few months. This reflects cultural and socio-economic differences southern Vietnamese are not as closely tied to their rural homes and the 'gap' between rural and urban conditions is usually large - as well as their general aspirations to 'escape' the poor circumstances of the countryside and/or make a life in the city.

It is also clear that being 'left-behind' is not the only form of separation and our sample is specifically designed in such a way as to enable us to explore what other kinds of strategic separations mean for family relations. Although the presence of children in Ho Chi Minh might be seen as a possible indicator of whether families are desiring to make a life permanently in the city or not, this does not necessarily mean that husband and wife are currently living together, nor that children will not at a later date be 'sent back', as we shall see. In contrast to a static conceptualisation of the left-behind, our data shows that migrant family strategies are fluid and negotiable. This holds true even in situation, like that pertaining in Hanoi, where 'leaving-behind' of children and, until quite recently young wives too, is strongly institutionalised. 
Table 4: The 'left-behind' relations in the sub-samples from Hanoi and Ho Chi Minh

\begin{tabular}{|c|c|c|c|c|}
\hline Name & Sex & Spouse & Children & Current Carer and Residence \\
\hline \multicolumn{5}{|c|}{ Hanoi Migrants } \\
\hline Linh & $\mathrm{F}$ & Together & $\begin{array}{ll}\text { - } & \text { Girl, } 7 \text { years } \\
\text { - } & \text { Boy, } 4 \text { years } \\
\end{array}$ & Left-behind with her mother \\
\hline Mai & $\mathrm{F}$ & Elsewhere & $\begin{array}{ll} & \text { Boy } 11 \text { years } \\
\text { - } & \text { Girl } 6 \text { years } \\
\end{array}$ & Left-behind with her mother-in-law \\
\hline Binh & $\mathrm{F}$ & Left-behind seasonally & $\begin{array}{ll}\text { - } & \text { Boy, } 10 \text { years } \\
\text { - } & \text { Girl, } 5 \text { years } \\
\end{array}$ & Left-behind with her mother-in-law \\
\hline Tran & $\mathrm{F}$ & $\mathrm{n} / \mathrm{a}$ & $\begin{array}{ll}\text { - } & \text { Girl, } 14 \text { years } \\
\text { - } & \text { Girl, } 13 \text { years } \\
\text { - } & \text { Boy, } 8 \text { years } \\
\end{array}$ & Let-behind with her mother-in-law \\
\hline Phong & $\mathrm{M}$ & Together & - $\quad$ Boy, 4 years & Left-behind with his mother \\
\hline Dung & $\mathrm{M}$ & Overseas & - $\quad$ Girl, 8 years & Left-behind with his Mother \\
\hline Tao & $\mathrm{M}$ & Left-behind & $\begin{array}{ll}\text { - } & \text { Girl, } 12 \text { years } \\
\text { - } & \text { Boy } 5 \text { years } \\
\end{array}$ & Left-behind with his wife \\
\hline Toan & $\mathrm{M}$ & Left-behind & $\begin{array}{ll}\text { - } & \text { Boy, school age } \\
\text { - } & \text { Girl, school age. } \\
\end{array}$ & Left-behind with his wife \\
\hline \multicolumn{5}{|c|}{ Ho Chi Minh Migrants } \\
\hline Hue & $\mathrm{F}$ & Together & - $\quad$ Boy, 7 years & With her \\
\hline Huong & $\mathrm{F}$ & Elsewhere & $\begin{array}{ll}\text { - } & \text { Boy, } 9 \text { years } \\
\text { - } & \text { Boy, } 4 \text { years } \\
\end{array}$ & With her \\
\hline Kieu & $\mathrm{F}$ & Left-behind & $\begin{array}{ll} & \text { Girl, } 7 \text { years } \\
\text { - } & \text { Boy } 4 \text { years } \\
\end{array}$ & Left-behind with her husband \\
\hline Chien & $\mathrm{F}$ & $\mathrm{n} / \mathrm{a}$ & - $\quad$ Boy, 7 years & With her \\
\hline Manh & $\mathrm{M}$ & Together & - $\quad$ Girl, 5 years & With him \\
\hline Hung & $\mathrm{M}$ & Elsewhere & - $\quad$ Boy, 4 years & Left-behind with his mother \\
\hline Thuat & $\mathrm{M}$ & Left-behind & - $\quad$ Boy, 7 years & Left behind with his wife \\
\hline Duong & $\mathrm{M}$ & Together & - $\quad$ Boy, 7 years & With him and his second wife \\
\hline
\end{tabular}

\section{Shifting Strategies and Complex Trade-Offs}

Our findings highlight the need to avoid seeing the 'left-behind' as a different set of people from the migrants in families (Jones and Kittisuksathit 2003). Many of our now migrant interviewees, had at various times also been 'left-behind' themselves at different times. This was most prominent in the case of women, particularly returning in the later stages of pregnancy for child-bearing or only first migrating after marriage after the first child was safely outside early infancy, or when subsequent children were weaned. However, it also occurred in the case of men, some of whom returned seasonally to follow rural occupations leaving wives in the city, others who felt that wives had relatively more workable incomegeneration opportunities in the city in the absence of significant capital, and yet others who felt they were now 'too old' to continue with 'hard' physical labour in the city.

Kieu and her husband's experience illustrates this dynamism. She is now migrating to Ho Chi Minh and working as a junk buyer whilst her husband is at home with her children far away in the Red River Delta. When her first child was a year old, she and her husband migrated for the first time, leaving their daughter behind with her parents-in-law whilst they migrated the long distance to Ho Chi Minh. They both returned to their home when she was expecting her second child and her husband migrated to nearby Hanoi to work during her late pregnancy and their son's early infancy so that he was nearby and could visit frequently. Once the child was weaned she joined her husband migrating to Hanoi whilst the children were left-behind but again the short-distance enabled her to visit the family for a few days every couple of weeks. Once her daughter reached school age they felt she needed more guidance than her grandparents could offer and by this time Kieu's parents-in-law had anyway became a bit older and needed some support themselves, so she and her husband agreed that he went back to the village and that she returned to Ho Chi Minh on her own. Earnings are higher in Ho Chi Minh than Hanoi so the family can survive off one higher rather than two lower sets of remittances, her daughter is old enough to do the cooking at home to help her husband, and 
she can save more than her husband because he 'could not' cook for himself in the city. Like many of the other couples, Kieu and her husband adopted different strategies of separation and togetherness at different points in their family's life cycle.

The dynamism of husbands and wives movements though contrasts with that of children, particularly for the Hanoi migrants: whilst some children were called from the countryside at times of illness (theirs or a grandparents) or sent back to the countryside for education, lowincome migrant mothers and fathers in Hanoi emphasised the 'impossibility' of bringing their children to the city with concerns revolving around the cost of adequate housing, food, education, and their foregone earnings. Whilst migrants to Hanoi constructed the city as an 'undesirable' place to raise children, many migrant parents to Ho Chi Minh, particularly those from provinces other than the Red River Delta, felt that city life potentially offered their children new opportunities, better education and better food, and some were willing/able to incur/bear considerable expense and hardship to make this a reality. The pattern of child movements reflected the fact that it was easier for parents to negotiate barriers to bringing children to Ho Chi Minh until the start of elementary, and certainly secondary school, when children were often sent back, because of the possibility of flexible nursery or home-based care or reciprocal child-care arrangements.

In these contexts then, parental or spousal separation may not be an enduring feature of migration, with dynamic and provisional strategies evolving in response to a variety of factors that include children's developmental needs and grandparents' capabilities. Significantly, the migrants overwhelmingly subscribe to social norms of family co-residence and justify their absence in terms of fulfilling their parental or marital roles in the current economic climate in which agricultural opportunities are insufficient, the importance of education is widely accepted and the 'real' cost of education (even for rural children at primary level) is growing. Whilst the motivation for migration is economic, at heart it is for these mothers and fathers about the desire to make a better life for their children. This involves complex trade-offs for husbands and wives many of whom endure 'miserable lives' in the cities to safeguard the nutritional security and educational continuity of their children. One female rubbish collector in Hanoi who had left her husband and children behind expressed a common aspiration: that her low paid work might make it possible for her children to gain a university education and enter the modern economy.

\section{Leaving Behind Children}

In almost all cases children who were left-behind were living with one parent and/or paternal grandparent(s) (see table 4 above and appendix 1 for further details). Whilst the consensus was that mothers should remain with infants during the key period of breastfeeding (at least 6 months) and ideally up until children began kindergarten at 3 years, some children were left within the first few months of life whilst other mothers resumed hard rural work around the village leaving infants in the daytime care of grandmother or other relatives. Indeed, many migrant mothers who had left children behind contrasted the negligence of leaving young children alone in the city during working hours with the normality of being cared for by grandparents in the countryside even when co-resident with mother. Whilst Mai (a porter) says that "It [would be] better to stay home because my child was still young", she came to Hanoi when her child was only 18 months old because she and her husband were "still poor" and "had nothing" and she presents her earning as "for" her baby. She emphasises that she did not "just wean and go" but invested considerable effort in socialising her baby into her mother-in-law's primary care.

Migrant mothers reported that they did not face any negative criticism from villagers for leaving their children because of the widely-recognised economic realities. For example, Mai feels that as a migrant "our children do not have the same care like those kids whose 
parents stay at home" but offers a justification common amongst Vietnam's migrants when she says that:

"I think a mother who stays but cannot provide for her children is not as good as migrant people like us. We come here to work because the money is quick. We work in the morning and have money in the afternoon. We have money to pay school fees. That's better than those staying at home. That's what I think. Those mothers who carry bricks at home are not paid for months. They have no money to pay school fees and the teacher sends their children home."

Although the migration of young married women disrupts strong social norms against the mothers of young children migrating for work (Hoang 2008), increasingly married woman in their peak child-bearing years are as well represented in migrant populations as married men (GSO 2005) ${ }^{8}$ and patterns of chain migration mean that there have been substantial shifts in social norms within communes where female migration has become more established. Binh (a CD seller in Hanoi) says that:

"In my home village, there are many people migrating to Hanoi. We all understand that because of the difficulties in life, people have to leave their children at home to go to big cities earning a living. No mother or father wants to leave their children behind... ... people do not think mothers, like me, are bad mothers because they leave their children at home to come here to earn a living not to go wandering aimlessly around."

Narratives like those offered by Mai and Binh play well within the official ideology of the doi moi era which selectively reinterprets traditional norms and promotes 'happy families' that are economically stable as a result of wife's as well as husband's productive income generation (Pham Van Bich 1999, Pettus 2003, Rydstrom 2006).

Despite holding strong social norms that parents should live with children, in the context of economic transition, migration offers the possibility for them to ensure their children's nutrition and continued education. As Linh (a porter in Hanoi) notes "I have to migrate for work when they are still young. I am worried about them. But I cannot do anything about that. If I want to provide for them, I have to migrate. But when I migrate, I cannot take care of them." The implications of parental absence are constructed by migrants in ways that are strongly gendered (both in relation to child and parent) and to the child's age. Migrants attempt to manage their parenting from a distance in various ways that go beyond the sending of regular remittances. It is notably that migrant mothers construct their visits home as about 'taking care' of their children whilst migrant fathers go home 'to visit'. Parental migration for work by mothers is constructed as a 'sacrifice' that is required of them as part of their obligations to their children. Migrant mothers and fathers relationships with their parents-inlaw or parents influenced their confidence in their capacity to look after their children. Even where migrant mothers and fathers were very happy with grandparent's care, they felt that it was still better for a child to live with its parents.

Migrants, including fathers, are deeply concerned about the emotional impact of parental absence on their children leading to an absence of proper 'sentiments' between parents and children. For example, Toan (a coal seller from Hanoi) notes that "In my opinion, migration makes me neglect to look after and take care of them and I am a bit far away from them

\footnotetext{
${ }^{8}$ Around half of men and women migrants to Hanoi and Ho Chi Minh are married and around $30 \%$ of women migrants like men who had moved in the past 5 years were already married when they first moved (GSO 2005). Of those that are married at first move, $88 \%$ already have at least one child. Of those who are married at first move but don't already have a child, $66 \%$ go on to have children after moving (as do 35\% of those who already have one child when they first move) (GSO 2005). Jensen et al's (2008: 18-19) study of women roving street vendors in Hanoi confirms this fact and further suggests that married women are increasingly migrating before and during peak child-bearing years: Of those in their sample migrating between 2006 and 2008, 28\% migrated before they have their first child, $14 \%$ between the birth of the first and second child and 58\% after their child-bearing was 'complete'.
} 
sentimentally... I cannot always be with them to bring them up to have heart-to-heart talks to them... I am working and living far away from my children and I think it is difficult for me to compensate for their lack of affections and fatherhood." In some cases, where it was clear that problems had emerged this had led to either parental return or the child's accompanying migration at least for a while. For example, at the time of our interview with Phong (a barber in Hanoi), he had sent his wife back temporarily for a few months because his son was not coping well and when his son starts school he plans to return home leaving his wife in the city because of his son's "psychology". He notes that: "I have found out that my son seems not to have sufficient sentiments from parents. We sometimes go back home, he tries to cling on to us. I usually tell my wife that we are away for a long time so our son lacks of sentiments from parents so he misses us."

Interestingly, the experience of migration has affected the migrants' ideals about parenting and they claim their relations with their own children. Whilst experiencing persistent discrimination as rural migrants in the city, including frequent rudeness and verbal abuse, these mothers and fathers commented very favourably on their observations of urban parentchild relations in comparison to rural parent-child relations. In particular they emphasised 'ways of speaking' to children in which they constructed rural parents as 'shouting' at their children, whilst urban parents were seen as speaking softly to them and as actively encouraging their learning. Many, like Phong, claim to have put this into practice with their own children. He says that he has learnt from city dwellers:

“...about children's psychology, yes, may be someone taught me how to know the time when a child has a swift wit, I have practiced it, and I have tried on my son. For example, the time when he learnt to speak and he learnt to reason everything around him, I could choose the best time to teach him"

Similarly, Binh says that:

"I have noticed that many families pay much attention to education their children, and I have learnt a lot from them about educating their children.... When going around selling things, I pay attention to the ways they take their children out, to teach them to behave and to speak with other people. In short, it is different from people living in the countryside.. For example, in the countryside, parents usually shout and scold when they talk with their children or speak to children with impolite words. Here, in the city, parents speak in gentle voice to their children... When I come home, I never beat my children. I talk to them in the evening in gentle voice"

These narrative strategies show how parenting relationships may be being revalued through separation and exposure to more cosmopolitan urban values.

Strategies of maintaining parenting from afar included fostering direct contacts with children's teachers through telephone conversations when away and personal visits when home. Traditionally fathers have been expected to play a strong role in guiding their children, and particularly their sons, in the education. It was notable that some parents, and especially fathers, felt that when children entered school that they needed to return to the countryside to support their child's education at home. Many reported the poor quality of rural education but the much greater cost, the real difficulties of school admission for migrant children in urban areas as a result of the household registration system, and the problems of out-of-school care prevented many from bringing children to study in the city.

The experience of those in our sample who did bring children with them appears to bear out such concerns. Some women migrants returned over long distances from the Red River Delta to Ho Chi Minh with babies as young as 9 months: these children were perceived to be too young to be left behind so far away. These women managed to look after their babies by taking turns looking after children with husbands, relatives or neighbours or in some cases by private nursery or home-based care. Once these infants reached 3 years, were easier to care for and able to attend public nursery care in their home villages, they were generally sent home. Other migrants to Ho Chi Minh from the Mekong Delta brought back young children 
and persuaded mothers or mothers-in-law to live with them in the city until nursery school age when they were sent back to the countryside. Still others had managed to obtain scarce places for children at nursery and then elementary schools in Ho Chi Minh. For them the challenge of keeping children in the city also involve the necessity to earn enough as a couple to manage the somewhat higher fees that non-residents are required to pay for entry, for at least one parent to have flexibility to drop off and collect children from school, the frequent necessity of taking children to dangerous and unhealthy workplaces, difficulty adequately supervising children's free time and supporting children's schooling and social development in cramped living conditions. Many who had negotiated these hurdles so far anticipated or had sent children back to the countryside for secondary schooling as barriers to access at this level were even higher and concerns for supervision of teenagers spare time were more complex.

Migrants leaving behind young children are trying to use the 'window of opportunity' when their children are outside the dangerous period of early infancy but still young enough to have straight forward care needs, and when grandparents may be fit enough to look after them, in order to accumulate the necessary resources to build a better future for the family. As children grow older, both male and female migrants feel that it is increasingly important to have at least one, but ideally both parents living with the children. This is because they have more complex needs for proper social development and moral guidance as well as support for education than grandparents alone can provide. Whilst the mother's presence is seen as especially important for growing girls, the father's presence is seen as particularly important for discipline and for guiding career choices, especially of boys. Many migrants are anxious about the long term effects of their absences on their relations with children. Most hope their children will understand their absences and underlying this fear, at least in part, is a concern that Toan spells out more explicitly: respectful and loving relations between grown children and ageing parents are vital not only in a material sense but also emotionally and spiritually in Vietnam (for the continuity of lineage): "You see, fatherhood plays an important part in bringing up children therefore I am so afraid that they will not obey me and my wife when they grow older"

\section{Leaving Behind Wives or Husbands}

Migrants also saw marital (as opposed to parent-child) co-residence as an ideal. Although 'visiting marriages' (Pham Van Bich 1999. Kabeer and Thi Van Anh 2002, Resurreccion and Khanh 2007) in which the husband migrated for work have a long history in Vietnam, particularly in the North, tolerance for spousal separation may have weakened as a result of changes in marriage practices and expectations that have increased the scope for conjugal intimacy (Summerfield 1997). Migrants justify their migration with their spouse in different ways: men tend to point to economic factors and women more explicitly to a range of emotional factors. However, depending on their circumstances, migrating together may afford little conjugal intimacy: many couples share small rooms with 5 or 6 other couples, others migrate to the same city but live separately with their work groups, with both only able to have sex together in visits to the countryside or hurriedly in borrowed rooms.

Spousal separation is dominated by anxieties which reflect gendered expectations of marital fidelity, sacrifice and self-discipline. Whilst wives who stay in the countryside are seen as 'left behind', husbands who remain there describe themselves as having 'sent their wife' to the city. Whilst left-behind wives must have faith that their husband's will not be tempted to get involved in 'social evils' or other relationships, left-behind husbands emphasise that women do not 'go around' the city, point to the social surveillance arising from the fact that women migrants share guest house rooms in the city with others from their village, and articulate their refusal to tolerate infidelity (in a context where divorce is deeply shameful for 
women). These normative positions belie the complexity of real life relationships. Our sample included husbands who had been abandoned by wives and who were prepared to take back adulterous wives as well as vica versa. Individual accounts show that despite fears that migrant causes divorce (Summerfield 1997), that migration plays into divorce in rather complex ways. For example, in Tran's case (porter in Hanoi) it is clear that migration offered an 'escape' for her already adulterous husband but was not the cause of his infidelity. Interestingly, she describes herself as 'separated' but has secured her position in her marital home entirely through good relations with her in-laws apparently by-passing her husband's wishes and will not divorce.

Trust is universally seen as functionally necessary for couples to live apart but whilst some migrants ground that trust in feminine virtues and male intolerance, others construct their conjugal relations as grounded in mutual belief, 'love' and understanding. Prevailing doublestandards mean that whilst women's main concerns revolve around 'economic' fidelity, men's are more focused on sexual fidelity (see Phinney 2008). For instance, when asked about her husband's sexual fidelity, one female migrant replied that her husband could not divorce her because she has been a 'good wife': in other words, she makes claims only for her husband's economic fidelity and she does this through her wifely performance. Toan offers a common male perspective with a long historical precedent that husbands have a right to be absent for work in his defense of his two swift divorces: "Do you want to ask me if my migration affected my marriage?.. Do you know how many men in my village are migrating to big cities looking for jobs like me? But none of their wives want to get divorced!... ... my house is not a market; no one can come in or go out whenever she wants". Other migrants offered more mutualistic interpretations though. For instance, Binh says of her and her husband that "we believe each other so strongly that we can let one of us go [for migration. If not] both would have to stay at home". Interestingly, Dung whose wife is working overseas grounds his attitude to his wife's fidelity in tolerance and sees this as a defining feature of masculinity: "If my wife no longer loves me, it's life. I never think of this end as we were together in the most difficult time and always shared our thoughts. We understood each other very much. That's my belief. In case of her changing I have to accept it... A man needs to be tolerant". It is clear that the experience of leaving behind a husband or wife is strongly nuanced by the character of a couple's relationship.

Left-behind husbands have to tolerate comment on the their adequacy as a breadwinner when their wives to work in the city and those without strong support from other close female relatives may also have to negotiate rural norms about men undertaking reproductive work. Several female respondents who had left husbands at home empathise with the difficulties their husband's experience whilst at the same time investing in constructions of their migration in ways that uphold conventional gender norms. In the Red River Delta, Resurreccion and Khanh (2007) found that left-behind husbands invoked women's traditional obligations even when they took up women's work in their absence as a means of coping with the way female migration destabilises conventional gender roles. We found that strong perceptions about women's hard working natures, the relative availability of incomegenerating work that requires little or no start-up capital for women rather than men in the city, and perceptions that women spend less and save more are also used to justify the decision for wives to migrate without husbands.

The data suggests caution in reading dis/empowerment into any specific arrangements of going and staying. Varying degrees of agency and compulsion were evident across all the categories of migration for men as well as for women. Even men who had left wife and children in the countryside and who offered highly conventional gender stereotypes justifying male migration complained of feeling homesick, of feeling removed from the everyday care of their children and close relations with them and simply desired to be able to make a decent living in the village. Others mentioned the impossibility of remaining and being poor in villages where all the men go away for work and many women migrants describe how they 
played a role, sometimes covertly, in their husband's decisions to migrate. Whilst women talk of being 'allowed' to go and men describe 'sending' their wives, reflecting prevailing conjugal power relations, it is clear that some women actively manoeuvre for migration whilst others are unable to resist pressure to go from husbands and in-laws. Contemporary government policy builds on traditional expectations that wives 'help' their husbands through contributing to productive household income in Vietnam: casting women's migration as parenting work obscures its contradictions with their obligations to provide everyday care for their children. Whilst this offers some women the discursive resources to negotiate for their own migration, it adds to the pressure that can be brought to bear to force other women to reluctantly 'accept the sacrifice' of their migration away from their family. Yet other women use being 'allowed' to go the city as a stepping stone to persuading husbands and children to join them and make their future there. For some women the city represented a potential escape from a 'rural life': some women fled to the city from disintegrating marriages and others refused to return to the countryside with husbands. However, for some becoming 'stranded in the city' represents a much more vulnerable situation than being 'left-behind': this is reflected in various cases where women are excluded from their natal villages after divorce, after the disintegration of adulterous relations or in one case because of the prolonged mental illness of a husband.

The depth of affection in marriages varies, but husbands and wives also worry about the impact of prolonged separation on the 'sentiments' in their marriages and stress the importance of 'having understanding'. Linh says that "sentimentally it is better to have your husband with you" and Binh agrees that "if we are away from each other for too long the sentiments between two people may be hurt." Several stressed that left-behind husband's may 'call their wives home' for a visit if they have been away for 'too long'. Even where families are working towards a strategy of settling in the city, and have managed to bring children to the city, husband and wife may not live together (such as in Huong's case). Part of the attempt to make a life in the city involves the onward migration of one of the couple for the time being. Inability to life 'together' as a family unit over the longer term, even minimally in the sense that at least one parent lives with the children particularly during their later schooling and teenage years, is perceived by migrants as a 'failure'. Despite the female migrants' efforts to portray their work as parenting, they all expressed strong feelings of grief and loss that they had to suppress to get on with their tasks. Tran openly says that she is a "poor mother" because of her absences. Another male migrant cried as he described his life as "a mess" because each member of the family was living separately because he could not fulfil his obligations to provide for them as a father should. Whilst migration for these young married men and women is about building a future for their families, at the same time it inevitably increases the strain on family life.

\section{Conclusions}

In conclusion, the evidence shows that 'leaving behind' children, wives or husbands involves complex trade-offs that are orientated to improving the prospects of the next generation. Migrant mothers and fathers use discursive strategies to justify leaving children behind and to re-present their absence for income-generation as doing important parenting work. At the same time, absent parents actively manage their parenting roles from afar through sending remittances, visits home and various means of keeping in touch with children's carers, children's teachers and children themselves. Nevertheless, absent parents remain extremely concerned with the emotional impact of their absence on their children, appear to have adopted 'new' parenting norms through migration, and many plan for one or both to return when the child is in school.

Migrant husbands and wives negotiate gendered social norms which involve deeply held double-standards. Wives express their accompaniment of husband's in more emotional terms but have most to fear in terms of marital infidelity from being 'left behind'. Husbands tend to 
offer more economic explanations for spousal separation or co-residence during migration and underlying expressions of trust between husband and wife, many husbands feel they have the power to retain control over their wives. Both male and female migrants closely link their understandings of the meaning of their absences to their performance of their social identities as fathers/husbands and mothers/wives. Notably male migrants as well as female migrants feel acutely the way their absence compromises their ability to parent their children emotionally, thus confirming the importance of "emotional and psychological struggles" entailed in leaving behind children/ spouses (Toyota et al 2007:157).

The views of migrants on their parenting and marital relations with left-behind children and spouses suggest that migration does improve the lives of the left-behind but at a cost. That cost includes the 'miserable life' of the migrant, and the 'lack of sentiments' between parents and children and husbands and wives. More significantly though the data strongly confirms the need to: avoid seeing 'the' left-behind as a distinct group; to recognise the fluidity and negotiability of the roles of 'staying at home' and 'going away to work'; and related to this the power relations reflected in being allowed to go for work, being 'sent back' or 'accepting the sacrifice' of separation from children. Gendered family relations of power and inequality are inscribed within these strategic separations and different 'scripts' about conjugal relations, virtue/obligation and love/understanding provided additional inflections to the meaning of particular sorts of separations or togetherness-es.

Our dataset is well positioned to explore the variety of forms of separation and togetherness that migrants experience and suggests that being 'left-behind' is a category within a range of several kinds of strategic family separations and togetherness-es found in the 'migrant life'. The intersection of specific intra-household power relations and wider institutional inequalities relating to place, gender and age gives meaning to particular strategic separations or reunifications. It follows from this that the relationship of being 'left-behind' can mean different things at different times and that to understand what it means in specific cases we need to see it unfolding over time in relation to other strategic separations and reunifications and to put it within the context of gendered family relations and wider institutional conditions.

\section{References}

Goodkind, D. (1996). 'State Agenda, Local Sentiments: Vietnamese Wedding Practices amidst Socialist Transformations', Social Forces 75 (2):717-742,.

GSO (Government Statistical Office) (2005). The 2004 Migration Survey: Major Findings, GSO, Hanoi.

Guest, P. (1998) The Dynamics of Internal Migration in Viet Nam, Discussion Paper 1, United Nations Development Programme, Hanoi.

Hoang, Lan Anh (2008). Social Structures and the Ability to Choose: Migration DecisionMaking in Rural Vietnam. Unpublished PhD Thesis, UEA, Norwich UK.

Hirschman, C. and Minh, N.H. (2002). 'Tradition and Change in Vietnamese Family Structure in the Red River Delta', Journal of Marriage and the Family 64(4): 1063 1079.

Jensen, R., JR, D. M. Peppard and VU, T. M. T. (2008). Women's Circular Migration in Vietnam: A study of Hanoi's roving street vendors. Paper presented at the Vietnam Study Conference held December 5- $7^{\text {th }} 2008$ at the National Convention Centre in Hanoi.

Jones, H. and Kittisuksathit, S. (2003). 'International Labour Migration and Quality of Life: Findings from Rural Thailand', International Journal of Population Geography 9:517530. 
Kabeer, N. and Thi Van Anh (2002). 'Leaving the Rice Fields, but not the countryside' in Shifting Burdens: Gender and Agrarian Change under Neoliberalism, ed. S. Razavi, Kumarian Press Inc., Bloomfield, CT, pp.109-150.

Locke, C, Nguyen Thi Ngan Hoa and Nguyen Thi Thanh Tam (2008). The Institutional Context Influencing Rural-urban Migration Choices and Strategies for Young Married Women and Men in Vietnam. First Research Report for the Project 'Linking Migration, Reproduction and Wellbeing', UEA, Norwich.

Pettus, A. (2003). Between Sacrifice and Desire: national Identity and the Governing of Femininity in Vietnam. Routledge: London and New York.

Pham Van Bich (1999). The Vietnamese Family in Change: The Case of the Red River Delta. Curzon Press, Richmond Surrey.

Phinney, H.M. (2008). "'Rice is Essential but tiresome; You Should Get Some Noodles" Doi moi and the Political Economy of Men's Extramarital Sexual Relations and Marital HIV Risk in Hanoi, Vietnam' American Journal of Public Health 98(4):650-660.

Resurreccion, B.P. and Khanh, H.T. (2007). 'Able to Come and Go: Reproducing Gender in

Female Rural-urban Migration in the Red River Delta', Population, Space and Place, $13: 211-224$.

Rydstrom, H. (2006). 'Sexual Desires and 'Social Evils': Young Women in Rural Vietnam' Gender, Place and Culture 13(3):283-301.

Summerfield, G. (1997). 'Economic Transition in China and Vietnam: Crossing the Poverty Line is Just the First Step for Women and Their Families' Review of Social Economy 55(2): 201-214.

Toyota, M., Yeoh, S.A. and Nguyen, L. (2007). 'Bringing the 'Left-Behind' Back into View in Asia: a Framework for Understanding the 'Migration-Left Behind Nexus', Population, Space and Place, 13:157-161. 


\section{Appendix 1}

Parenting of Hanoi Preliminary Sample

\begin{tabular}{|c|c|c|c|c|c|}
\hline Name & Sex & Spouse & $\begin{array}{l}\text { 'Current' age of } \\
\text { children }\end{array}$ & Migration away from children & Carer \\
\hline Linh & $\mathrm{F}$ & $\begin{array}{l}\text { Migrating } \\
\text { together }\end{array}$ & $\begin{array}{ll} & \text { Girl, } 7 \text { years } \\
- & \text { Boy, } 4 \text { years } \\
\end{array}$ & $\begin{array}{l}\text { First migrated when second } \\
\text { child was } 18 \text { months and first } \\
\text { was nearly } 5 \text { years. } \\
\end{array}$ & Her mother \\
\hline Mai & $\mathrm{F}$ & $\begin{array}{l}\text { Migrating } \\
\text { separately }\end{array}$ & $\begin{array}{ll}\text { - } & \text { Boy } 11 \text { years } \\
\text { - } & \text { Girl } 6 \text { years }\end{array}$ & 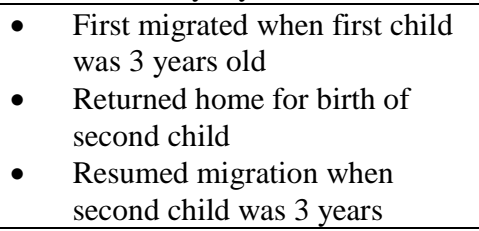 & Her mother-in-law \\
\hline Binh & $\mathrm{F}$ & $\begin{array}{l}\text { Left-behind } \\
\text { seasonally }\end{array}$ & $\begin{array}{ll}\text { - } & \text { Boy, } 10 \text { years } \\
\text { - } & \text { Girl, } 5 \text { years }\end{array}$ & $\begin{array}{l}\text { First migrated when } 2^{\text {nd }} \text { child } \\
\text { was } 2 \text { years old }\end{array}$ & Her mother-in-law \\
\hline Tran & $\mathrm{F}$ & 'Separated' & $\begin{array}{ll}\text { - } & \text { Girl, } 14 \text { years } \\
\text { - } & \text { Girl, } 13 \text { years } \\
\text { - } & \text { Boy, } 8 \text { years }\end{array}$ & $\begin{array}{l}\text { Migrates to join husband who } \\
\text { is being unfaithful and failing } \\
\text { to send remittances when } \\
\text { daughters are } 4 \text { and } 5 \text { years old } \\
\text { - } \quad \text { Returns for birth of son } \\
\text { - Resumes migration when son is } \\
2 \text { years old }\end{array}$ & Her mother-in-law \\
\hline Phong & $\mathrm{M}$ & $\begin{array}{l}\text { Migrating } \\
\text { together }\end{array}$ & - $\quad$ Boy, 4 years & 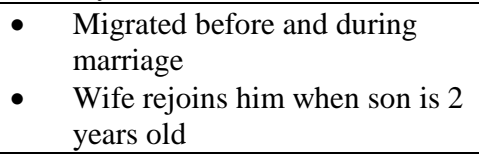 & His mother \\
\hline Dung & $\mathrm{M}$ & $\begin{array}{l}\text { Migrating } \\
\text { overseas }\end{array}$ & - $\quad$ Girl, 8 years & $\begin{array}{l}\text { Migrated when his only child } \\
\text { was 4years } \\
\text { Returned home for a few } \\
\text { months after wife went } \\
\text { overseas when daughter was } 6 \\
\text { years } \\
\text { - Resumed migration }\end{array}$ & His Mother \\
\hline Tao & $\mathrm{M}$ & Left-behind & $\begin{array}{ll}\text { - } & \text { Girl, } 12 \text { years } \\
\text { - } & \text { Boy } 5 \text { years }\end{array}$ & $\begin{array}{ll}\text { - } & \text { Migrated before and during } \\
\text { marriage } \\
\text { - } & \text { Returns home briefly for births } \\
\text { - } & \text { Visits monthly } \\
\end{array}$ & Wife \\
\hline Toan & $\mathrm{M}$ & $\begin{array}{l}\text { Twice } \\
\text { Remarried }\end{array}$ & $\begin{array}{l}\text { - } \quad \text { Boy, school age } \\
\text { - } \quad \text { Girl, school age. }\end{array}$ & $\begin{array}{ll}\text { - } & \text { Migrated before and during } \\
& \text { marriage } \\
\text { - } & \text { Returns home briefly for births } \\
\text { - } & \text { Visits monthly }\end{array}$ & Wife \\
\hline
\end{tabular}


Parenting of Ho Chi Minh Preliminary Sample

\begin{tabular}{|c|c|c|c|c|c|}
\hline Name & Sex & Spouse & $\begin{array}{l}\text { 'Current' age } \\
\text { of children }\end{array}$ & Birth and Parenting arrangements & Current Carer \\
\hline Hue & F & $\begin{array}{l}\text { Migrating } \\
\text { together }\end{array}$ & $\begin{array}{ll}\bullet & \text { Boy } \\
\bullet & 7 \text { years }\end{array}$ & $\begin{array}{l}\text { - } \quad \text { Born at mother's natal home as mother-in-law not fit } \\
\text { - Couple first migrate with son when he is around } 6 \\
\text { months } \\
\text { - After a few months, son sent to paternal grandparents } \\
\text { and returned when } 3 \text { years old } \\
\text { - } \quad \text { No school enrolment but attends private classes }\end{array}$ & - $\quad$ Herself \\
\hline Huong & F & $\begin{array}{l}\text { Migrating } \\
\text { separately }\end{array}$ & $\begin{array}{ll} & \text { Boy } \\
- & 9 \text { years } \\
\text { - } & \text { Boy } \\
\text { - } & 4 \text { years }\end{array}$ & $\begin{array}{ll} & \text { Parents met and married in city } \\
\text { - } & \text { Living together in city before babies arrives } \\
\text { - } & \text { Both boys born in city } \\
& \text { Cared for by mother whilst she worked until started } \\
\text { public nursery school at } 4 \text { years and } 3 \text { years } \\
\text { respectively }\end{array}$ & - $\quad$ Herself \\
\hline Chien & $\mathrm{F}$ & Widowed & $\begin{array}{ll} & \text { Girl } \\
- & 6 \text { years }\end{array}$ & $\begin{array}{ll} & \text { Parents living together in city when born } \\
\text { - } & \text { Daughter born in city } \\
\text { Private nursery from } 9 \text { months old (500,000 VND } \\
\text { nursery fees) }\end{array}$ & $\begin{array}{ll} & \text { Herself }\end{array}$ \\
\hline Manh & $\mathrm{F}$ & $\begin{array}{l}\text { Migrating } \\
\text { together }\end{array}$ & $\begin{array}{ll} & \text { Boy } \\
- & 7 \text { years }\end{array}$ & $\begin{array}{ll}\text { - } & \text { Parents both living together in HCM before birth } \\
\text { - } & \text { Born in HCM in accordance to father's wishes } \\
\text { - } & \text { Has always lived with parents } \\
\text { - } & \text { Attends public elementary school } \\
\text { - } & \text { Father prime carer as mother works long hours } \\
\end{array}$ & - $\quad$ Himself \\
\hline Hung & $\mathrm{M}$ & $\begin{array}{l}\text { Migrating } \\
\text { separately }\end{array}$ & $\begin{array}{ll}- & \text { Girl, } \\
& 5 \text { years }\end{array}$ & $\begin{array}{l}\text { Child born in rural home at district hospital } \\
\text { - } \quad \text { Child left-behind with his wife in the village. } \\
\text { Wife and child joined him in city for } 5 \text { months when } \\
\text { daughter was } 4 \text { years old. She sold drinks at a } \\
\text { construction site whilst looking after child. } \\
\text { - Wife migrated to Binh Duong to work as maid and } \\
\text { child sent back to village }\end{array}$ & $\begin{array}{ll} & \text { His } \\
& \text { mother }\end{array}$ \\
\hline Thuat & $\mathrm{M}$ & Left-behind & $\begin{array}{ll}- & \text { Boy } \\
- & 4 \text { years }\end{array}$ & $\begin{array}{l}\text { - } \quad \text { Wife was migrating with husband when fell pregnant } \\
\text { - } \quad \text { Returned to marital home for birth } \\
\text { was over } 2 \text { years of age } \\
\text { - } \quad \text { Wife and son now left-behind again. } \\
\end{array}$ & - $\quad$ His wife \\
\hline Duong & M & 'Remarried' & $\begin{array}{ll} & \text { Boy } \\
\cdot \quad & 7 \text { years }\end{array}$ & $\begin{array}{ll}\text { - } & \text { Son of first marriage } \\
\text { - } & \text { Parents living together in HCM when born } \\
\text { - Sent wife to his natal home for birth but she returned to } \\
\text { HCM with son aged } 4 \text { months } \\
\text { Son sent to private nursery at } 3 \text { years so mother can } \\
\text { work } \\
\text { Mother left and son sent to paternal grandparents for } 6 \\
\text { months } \\
\text { - } \quad \begin{array}{l}\text { Father brought son back to city as he was missing him } \\
\text { Son not at school because of psychological problems } \\
\text { that father attributes to mother's departure }\end{array} \\
\end{array}$ & $\begin{array}{ll} & \text { His } \\
\text { second } \\
\text { wife }\end{array}$ \\
\hline
\end{tabular}

